\title{
LEGAL PROTECTION TO MAKING CRAFTS GERABAH (BOSO MARE) TRADITIONAL KNOWLEDGE COPYRIGHT IN THE MARE ISLAND, TOWN OF TIDORE ISLANDS, INDONESIA
}

\begin{abstract}
Fatma Laha
Faculty of Law, Khairun University, Indonesia

Abstract

Research Concerning Legal Protection to Making Crafts Gerabah (Boso Mare) Traditional Knowledge Copyright in the Mare Island, Town of Tidore Islands, focused on the craft Gerabah (Boso Mare) mechanism. This research is to (1) know the extent of legal protection to making craft Gerabah (Boso Mare) traditional knowledge copyright in the Mare Island, Town of Tidore Islands (2) knowing Mare Island people's understanding of making craft Gerabah (Boso Mare) as traditional knowledge copyright. The research was conducted in Mare Island community. This type of research is normative with data collection techniques through field and literature study. Sources of data obtained in the form of primary and secondary data. Data analysis technique used is qualitative descriptive analysis. The results show that the people of Mare Island do not know about the importance of legal protection to making crafts Gerabah (Boso Mare) as traditional knowledge, the community does not know the registration procedure to register the craft Gerabah (Boso Mare) to the Directorate General of Intellectual Property Rights and the Regional Office of the Ministry of Law and Human Rights of North Maluku. Lack of socialization from Local Government so that people think that craft Gerabah (Boso Mare) hard to imitate, people believe that only the people of Mare Island alone can make crafts Gerabah (Boso Mare). In addition, without registered craft Gerabah (Boso Mare) products still sold in the market. Legal protection to making crafts Gerabah (Boso Mare) the effective participation of all components such as Local Government, Village Government and related agencies and local communities, especially the craftsmen Gerabah (Boso Mare).
\end{abstract}

Keywords: Indonesia, Copyright, Protection

DOI: $10.7176 /$ IAGS/74-06

Publication date:July $31^{\text {st }} 2019$

\section{Introduction}

Indonesia as an archipelago has a rich diversity of arts and cultures, this is in line with the diversity of tribes, nations and religions that as a whole is a national potential that needs to be protected. Protection of the potential to this diversity is a derivation of copyright law protection that is absolutely necessary because without legal protection, will certainly affect the work of the creators to create on the results of his creation.

Patricia Loughlan defines Copyright is a form of ownership that grants the holder the exclusive right to monitor the use and utilize an intellectual creations, as the creations set out in the category of copyright, such as literature, drama, music and art work as well as sound recordings, films, radio and television broadcasts, through propagation (publishing) (Afrillyanna Purba, 2009:25).

Copyright rules have been in existence since the Dutch colonial era with the publication of Auteurswet 1912 based on the idea of Law of the Republic of Indonesia No. 6 Year 1982 on Copyright which amended by Law of the Republic of Indonesia No. 7 Year 1987, then amended with Law of the Republic of Indonesia No. 12 Year 1997 and amended again with Law of the Republic of Indonesia Number 19 Year 2002. Then the Copyright Law is replaced by Law of the Republic of Indonesia No. 28 Year 2014. (Gatot Supramono, 2010:1). From the regulations side, it appears that the law's view of copyright is different from the views of society today. The law sees copyright as the property of the individual because of the western background of individualistic and materialistic thought, while the people still view copyright as a common property based on the nature of togetherness and mutual help.

It can be found in the manufacture of applied art that is Gerabah. Craftsmen Gerabah in Indonesia especially in the regions, not just one person who worked, but reproduced by others because the creator has limited ability. Earthenware handicrafts Gerabah in Indonesia and some pottery-producing areas can be functioned in meeting the needs of daily life.

Traditional knowledge encompassing traditional artworks that include literary, artistic, or scientific works, performances, invention, scientific discoveries, designs, brands, names and symbols, undisclosed information, and all other traditional based and innovations caused by intellectual activity in industrial, scientific and literary or artistic fields. Gerabah which is a tradition-based notion that shows on a system of knowledge, creations, information and cultural expresions that have generally been passed on from generation to generation, so that it is deemed to be closely related to a particular society or region. 
Another opinion revealed that traditional knowledge is a term used to describe a form of knowledge shared by a group of people used for generations directly related to the environment or nature. It is also reinforced by Henry Soelistyo's opinion that states that traditional knowledge is knowledge whose status of position or use is part of the cultural tradition of society. In relation thereto Law of the Republic of Indonesia Number 28 Year 2014 on Copyright, Article 38 Paragraph 1 stipulates that the Copyright on traditional cultural expression is held by the State of Copyright on traditional knowledge which must be guaranteed protection and legal certainty.

But in the legal aspect, the applied art of Gerabah is a traditional craft typical of Mare Island is not yet a legal protection to protect a work of creation from Mare Island community. In addition, Gerabah Crafts in Mare Island is not only a tool to help people's daily life, but also become one of the tools that must exist during traditional ceremonies in the Kingdom of Tidore, so the need for legal protection against the manufacture of Gerabah from Mare Island. The Copyright Law contains the provision that all intellectual works created by a Creator based on his intellectual ability require the sacrifice of time, energy, thought, and cost.

The expression of traditional culture and the copyright of creatures whose creators are not known has been regulated in Article 38 of Law of the Republic of Indonesia Number 28 Year 2014 on Copyright. The state holds the copyright over traditional cultural expressions and copyright over creatures whose creators are unknown. States should inventory, safeguard and preserve traditional cultural expressions, and the use of traditional cultural expressions should take account of the living values of the carrier society.

It is the duty and responsibility of the community, the Village Government and the Regional Government to pay special attention to the art of Gerabah (Boso Mare) in the event of registration at the Regional Office of the Ministry of Law and Human Rights of North Maluku to obtain legal protection. Although not as much as other industrial products, the applied art (Gerabah) is historically the traditional culture of the Indonesian nation so it needs to be preserved and protected. Through these efforts it is expected that there will be no piracy either by the people of Indonesia itself or by entrepreneurs from other regions/countries. The problem to be discussed in this paper is how to legal protection to making crafts Gerabah (Boso Mare) traditional knowledge copyright in the Mare Island, Town of Tidore Islands? and how to Mare Island people's understanding of making craft Gerabah (Boso Mare) as traditional knowledge copyright?

\section{Literatur Review \\ A. Art of Gerabah}

Gerabah began to be known people since thousands of years ago, even from archeological data states that since prehistoric times, when humans began to grow crops, this Gerabah craft began to be known to people. It is estimated that this Gerabah craft comes from China around 4000 years before Christ. Initially people make Gerabah for household appliances, for example cauldrons, jars, jugs and others that are all made of clay that is burned.

In the next development, this Gerabah is not always only for household goods, but also for building materials, such as red brick, tile, and finally ceramics, such as jars and tiles. Because of the development of Gerabah into ceramic materials, people classify Gerabah into two types, namely (Widarto, 1995:9):

a. Gerabah that can absorb water, such as red brick, tile, piggy bank, stove, cauldron, pitcher and others.

b. Gerabah that is not able to absorb water or known as ceramic crafts, such as ceramic tiles, cups, dishes, jars and others.

The shape and usefulness of Gerabah varies, ranging from merely decorative items of the room to household appliances such as jars, stoves, bowls, jugs, and others. Sizes vary as well. There are small ones, such as various souvenir items, key chains and so on; of medium size, such as various kitchen utensils; and there is also a giant size of a height of 3 meters. The way of formation with direct hands such as coil, slab or finger massage is a technique of forming of traditional Gerabah that is free to make the desired shapes. The shape is not always symmetrical This technique is often used by artists or fans of Gerabah. This Gerabah is a creative endeavor, then the problem of shape, size, and decorations always appear "new creations".

\section{B. Definition of Intellectual Property Rights}

The conception of Intellectual Property Rights (IPR) is based on the idea that the intellectual work that man has produced requires labor, time and cost. The existence of these sacrifices makes the work that has been produced has economic value because of the benefits that can be enjoyed. Based on the concept, it encourages the need for awards for the work that has been produced in the form of legal protection for IPR. The purpose of providing legal protection is to encourage and grow the spirit of work and create.

Substantively, the definiton of IPR may be described as a right to property arising or born out of human intellectual ability. HKI is categorized as a right of wealth considering that IPR ultimately produces intellectual works in the form of; knowledge, art, literature, technology, where in realizing it requires labor, time, cost and mind. The existence of these sacrifices makes the intellectual work to be of value. If coupled with the economic benefits that can be enjoyed, then the inherent economic value foster the conception of property to the 
intellectual works. Departure from the above explanation, Mahadi said, not be given clear explanation about the origin of the word "intellectual property rights", the word "Intellectual" used in the sentence, unknown tip end (Budi Agus Riswandi and M. Syamsudin, 2005:31).

As a way to balance the importance of individual's personal role with the public interest, the IPR system is based on principles.

a. Principle of Justice, based on this principle, the creator of a work or other worker bearing fruit from his or her intellectual ability is reasonably rewarded.

b. Economic Principles, in this principle an ownership is reasonable because of the human economic nature which makes it a necessity to sustain life in society.

c. The Cultural Principles, in essence, the work of man aims to enable life, then from that work there will arise a motion of life that must produce more works again. Thus, the growth and development of human works is very important for improving the living standards, civilization, and human dignity.

d. The Social Principles, granting of rights by law should not be given solely to the interests of the individual, but must satisfy the interests of the whole society.

Basically, IPR can be categorized into two parts, that is: (OK. Saidin, 2010:10)

1) Copyrights consisting of copyrights and rights related to copyright (neighboring rights).

2) Industrial Property Rights consisting of:

a) patent;

b) trade mark;

c) industrial design.

\section{Traditional Knowledge}

The term traditional knowledge is often equated with the term indigenous knowledge. Though these two terms have differences from each other. Indigenous knowledge is used to identify knowledge maintained by traditional societies. Indigenous knowledge must be traditional knowledge.

In contrast, traditional knowledge is not necessarily indigenous knowledge. In reality, traditional knowledge has much in common with indigenous knowledge in terms of its distribution, its scope, its diversity. Consequently, it is appropriate to place the position of indigenous knowledge as part of traditional knowledge (Tim Lindsey, et.al., 2011:361).

The scope or categories of traditional knowledge include knowledge, agriculture, scientific knowledge, technical knowledge, ecological knowledge, medical knowledge, (including medicines and related medical acts), biodiversity-related knowledge, folklore expressions in the form of music, dances, songs, crafts, designs, stories and artwork, language elements such as names, geographical indications, and symbols, as well as movable cultural objects. Not included in the scope of traditional knowledge are items not caused by intellectual activity in the fields of industry, science or literature or artistic fields such as human fossils, language in general, inheritance in the broadest sense.

Traditional knowledge is a knowledge developed in the past, but it still continues to be developed. Most of Traditional knowledge is a natural product used for generations and is often collected and published by anthropologists, historians, plant experts or researchers and other observers. However, traditional knowledge is not static because traditional knowledge develops and produces new information as an improvement or adaptation to various state changes.

One of the reasons for the lack of clarity about the rational protection of different meanings is given to the concept of protection. Some defitions of this concept are in the context of intellectual property rights that protection basically means the exclusion of unauthorized use by third parties. Other awards, that protection as a tool for selecting traditional knowledge from usage that may erode traditional knowledge or negative impact on the life or tradition of the community that develops and implements traditional knowledge. The protection here has many positive roles and supports traditional knowledge as the tradition and source of the livelihood of the community.

Overall, the main reason to provide protection against traditional knowledge that is:

a. Justice considerations;

b. Conservation;

c. Maintain traditional culture and practice (lifestyle);

d. Prevent confiscation by unauthorized parties against traditional knowledge components, and

e. Develop the use and importance of traditional knowledge.

In the protection of traditional knowledge there are 4 principles that are in the local community, namely: recognition, protection, profit sharing, and the right to participate in decision making. An additional principle that can be applied to traditional knowledge in the form of moral rights, namely prior informed concern (information first). 
The problem of traditional knowledge is a very important aspect strived by countries that have potential in this field to get legal protection. However, theoretically traditional knowledge itself is actually very possible to be protected. There are two ways that mechanisms can be implemented within the framework of protecting traditional knowledge, namely legal protection and a non-legal form.

\section{Copyright Concept}

Subject to the provisions of Article 1 paragraph (1) of Law Number 28 Year 2014 regarding Copyright, copyright is an exclusive right of the authors who arise automatically on the basis of a declarative principle after a work is manifested in a tangible form without prejudice to restrictions in accordance with the provisions of the law.

The concept of copyright protection began to grow rapidly since the invention of printing press by $\mathrm{J}$. Gutenberg in the middle of the fifteenth century in Europe. Needs in this field arise because with the printing press, especially copyrighted works of paper easily reproduced mechanically. It was these events that originally cultivated copyright.

In the Britain the use of the term copyright first evolved to illustrate the concept of protecting publishers from duplicating books by others who did not have the right to publish it. This protection is not given to the creator but to the publisher. Protection is intended to provide guarantees for the issuer's investment in financing the printing of a work. After Britain, following following the granting of certain rights to authors in France arising as a result of the French Revolution. Copyrights in subsequent developments transformed into exclusive rights for authors, whether to engage in economic exploitation or the rights to other facilities relating to his work. (Yusran Isnaini, 2010:1)

The basic principles contained in copyright, that is:

1. The protected copyright is a tangible and original idea.

From this principle some principles are derived, i.e.:

a. A work must have originality in order to enjoy the rights granted under the Law.

b.A work is copyrighted if its creation is manifested in writing or other material forms.

c. Since copyright is a special right, no one else may exercise that right except by the creator's permission.

2. Copyrights arise by itself (automatic).

3. A work does not necessarily need to be published for copyright.

4. The copyright of a work is a right recognized by law (legal right) that must be separated and differentiated from the physical mastery of a creation.

5. Copyright is not an absolute right (Eddy Damian, 2002:99).

The definition of copyright as set forth in Article 1 No. 1 of the Copyright Law of 2014, can be seen that copyright as an exclusive right. The existence of an exclusive right is firmly attached to the owner or its bearer which is the personal power of the creation concerned.

The existence of an exclusive right after a creation is realized and since that time the right shall begin to be exercised. By an exclusive right of a creator/copyright holder has the right to announce, reproduce his/her creation and give permission to the other party to perform such act. A creation that has been manifested by a creator who at the same time as a copyright holder can announce in such a way as to exhibit or staging so as to be known by others.

In accordance with Article 5 paragraph (1) of Copyright Law of 2014 the inherent moral rights of the Creator for:

a. Keep or not to mention his name on the copy in connection with the use of his creations to the public;

b. Using his real name or disguise;

c. Converts his creations in accordance with propriety in society;

d. Change the title and sub-title of a creation; dan

e. Defend its rights in the event of distortion of creation, mutilation of creation, modification of creation, or things that harm the self-respect or reputation.

Various international copyright literature (see Stewart, Bainbridge, Copinger, etc.) and copyright law provisions in various countries, including Indonesia, know that the basic concepts of copyright protection are as follows: (Otto Hasibuan, 2008:65)

a) The copyrighted is a tangible and original idea. The existence of a tangible and tangible form (expression) and something tangible it is original or not the result of plagiarism is a condition that must be met in order to enjoy the protection of copyright law.

b) Copyright exists by itself (automatic). A copyright exists when a Creator embodies his idea in a tangible form which can be a song composed of elements of melody and poetry or lyrics and has been recorded or written.

c) A Work does not necessarily need to be announced for copyright In the existence of an idea, a Creation is born. Created creations can be announced (to make public) and can not be announced. Unpublished 
or Unpublished Works of the two may obtain the copyright. For example, a songwriter, after recording his song (containing poems and melodies) in the cassette tape, kept the tape in the closet without any attempt to announce it through a sound recording producer. Although not announced, the copyright of the song is in the Creator.

d) The copyright of a Work is a legal right that must be separated and must be distinguished from the physical acquisition of a Work Someone buys a cassette or CD of a song, meaning that the person is the owner of the cassette or CD containing the songs, but he is not the copyright owner of the songs or music present in the cassette or CD. If someone reproduces a cassette or CD of a song he bought for resale, that person has infringed copyright.

e) Copyright is not an absolute right as it is expressed in the discussion of the nature of copyright, conceptually copyright does not recognize the full monopoly concept so that it may be that a Creator creates a Creation similar to that of a former Creation and is not deemed to infringe copyright.

Article 68 of Law Number 28 Year 2014 states that the provisions on copyright registration are not an obligation to obtain copyright. Copyrights are automatically obtained, for those who are not registered still obtain legal protection. However, registration is required as a preliminary proof of the copyright owner (Regulation of the Minister of Law and Human Rights). The registration of a work in the General Register of Works shall be made on the request made by the creator or by the copyright holder or his proxy, while the legal power of a registration of the creation shall be erased due to the removal of the request of a person or legal entity whose name is recorded as the creator or copyright holder, or declared null and void by a court decision that has obtained permanent legal force (Abdul R. Saliman, 2006:186).

A person's copyright has been violated by someone else, so the law can be taken, both criminal and civil. By virtue of civil law, the copyright holder is entitled to file a lawsuit against the Commercial Court for a copyright infringement that occurs in order to seizure of the announced item or the reproduction of the work.

\section{Research Method}

The type of research the author uses is Normative research which is a study of the norms and rules of legislation that have been made and implemented in the community related to the prevailing events or reality. Research conducted in Mare Island, District of South Tidore, Town of Tidore Islands. Mare Island is an inhabited small island, administratively entering into the government territory of South Tidore District, Town of Tidore Island. On this island there are two villages, namely Marekofo Village and Maregam Village. The location of this research in Mare Island precisely in the Village Maregam because this village is one village in Mare Island who have a livelihood as a maker of more Gerabah.

The types and sources of data in the study are as follows (1) Secondary Data, in the form of legal materials and regulations of applicable Invites, books, research results and internet, which is directly related to the problems that the authors discussed, (2) Primary data obtained directly from the results of field research through interviews and literature.

Data collection techniques are done is as follows (1) Field research is the collection of data obtained directly from the location of research in the form of data collection from interviews related to the issues discussed by the author, (2) Library research is the collection of data in the form of a number of data from the community and through books, articles or other directly related to the discussion of research that the authors discuss.

Technique Analysis of data used by this researcher to be able to analyze data obtained by using descriptive qualitative data analysis, where researcher will reveal facts found in field and give detail description about problem which discussed in this research.

\section{Results and Discussion}

\section{A. Legal Protection to Making Crafts Gerabah (Boso Mare) Traditional Knowledge Copyright in the Mare Island, Town of Tidore Islands.}

Gerabah or otherwise known as Boso Mare is a handicraft performed by a woman who is said to be the first inhabitant of Mare Island. She is the only woman who gives a general overview of how to make the Boso Mare. The first person to make Gerabah or Boso Mare is a woman named Mo're this word in the old spelling Tidore has Meaning $\underline{M o}$ meaning she is a woman, while $\underline{R e}$ means here. Mo'Re first discovered the pottery in the days of Momole leadership at Tidore at that time. Approximately 1000 years ago. Because the people who make these Gerabah are only certain people or people who inhabit the island, but the way the maker of Gerabah is still limited because the materials and tools in use is still difficult to find.

The early community of Mare Island to make Gerabah or Boso Mare in the year 1797 in addition to using the community as a tool to help the needs of household Gerabah or Boso Mare also made as a medium of exchange or in the know with Barter at the time. Along with the development of the era then the model and the way the makers also change as more and more people make changes then the model of making also change. The development of the world increasingly rapidly, the equipment needs more sophisticated but the people of Mare 
in particular and in general the people of North Maluku still use tools such as forno, ngura-ngura and so on in order to meet the needs of the family.

According to Usman Alting, before Indonesia's independence of people's life is still a crisis with the tools of necessity, the people of Mare has been able to contribute greatly to the people of North Maluku in this case is Gerabah or known to the public eye that is Boso Mare. (Usman Alting, interview: October 25, 2017).

There are various forms of Gerabah or handicrafts in the local language called (Boso Mare) among others:

a) Ngura-Ngura (Bura)

Ngura-Ngura or in the Tidore language called Bura is a tool used to create various types of cakes manually.

b) Balangan (Boso)

Balangan or Boso is a kind of Gerabah made by Maregam society with the purpose of being used as a kitchen tool for cooking fish, medicines and so forth.

c) Forno (Keta)

Forno or Keta is one of the handicrafts community of Maregam Village which is used as a tool for making sago.

d) Tempat Dupa (Hito)

Tempat Dupa or Hito usually used by the Tidore community as a burning incinerator in customary ritual activities

e) Balangan Kecil (Boso Kene)

Balangan Kecil or known as Boso Kene is one of the craft of Maregam society that is used during the ritual activities of Tidore society, for example: salai jin, circumcision and tahlilan.

According to Adam Fatah, Gerabah craft (Boso Mare) has various forms and their respective uses but from the excess has not been signed to obtain legal protection of Gerabah (Boso Mare). The people of Mare Island do not understand about the traditional knowledge possessed in the form of Gerabah (Boso Mare) Mare Island people thought do not need to be registered because the people already know that the Gerabah (Boso Mare) comes from Mare Island and is the center of the craft of making pottery (Boso Mare) which is in North Maluku (Archive, History of Gerabah Boso Mare).

An intellectual work can be said to be Traditional Knowledge when it grows and communally belongs to community. A knowledge can be said to be Traditional Knowledge whenever (Arif Lutviansori, 2010:96):

1) Taught and implemented from generation to generation;

2) It is knowledge of the environment and its relation to everything;

3) Be holistic, so it can not be separated from the community that build it;

4) It is a way of life that is used jointly by the community, and hence there are community values.

This was also explained by one of the Heads of the Tidore Islands City Legislation Agency. Murad Polisiri. When interviewed he said that:

Will be made the Regional Regulation (Perda) initiative about the protection of customs Tidore consultants and in it will be one of the points of discussion or Article governing the matter of regional recognition customs and the matter of Gerabah will be an input to make the Perda, but if without in making the regulation of making Gerabah (Boso Mare) will be included in the territory of indigenous people of Mare Island, Town of Tidore Island. It is hoped that this becomes a separate section to be communicated by the executive to be pushed into a proposed law by the executive. Given the manufacture of Gerabah (Boso Mare) as the original work of the Mare Island community should be given legal protection.

Protect the creations unknown to the creator and can be categorized as Folklore, UNESCO and WIPO has undertaken various attempts to regulate it. On the initiative of these two international organizations, in 1976 the Folklore arrangement was published in Tunis Model Law on Copyright for Developing Countries. Tunis Model Law was developed by UNESCO in cooperation with WIPO as a guide to the establishment of a national law that regulates the protection of Copyright in the legal system of developing countries. Another undertaking is the United Nations initiative to recommend a Draft Declaration of the Rights of Indigenous Peoples which in Article 12 regulates the importance of traditional community rights to practice and revitalize their culture and customs, including the right to realize a special law on knowledge protection traditionally, the government needs to set some key points in the Act, he is between them:

a) Term

The term used should be traditional knowledge rather than other terms such as folklore. This is because the notion of traditional knowledge is broader and includes folklore.

b) Scope

The scope of traditional knowledge should not only be limited in the field of technology and art, but can also include human efforts that are manifested in various human expressions and traditional methods. 
c) Procedure of licensing on the development of a traditional knowledge by other parties outside the traditional knowledge community.

d) It should be emphasized who the owner of the traditional knowledge

Specific laws on the protection of such traditional knowledge need to govern who should have traditional knowledge, whether the community collectively is represented by the adat head or held by the state for the benefit of the community who owns and inherits that knowledge. This assertion needs to be made to facilitate permit request procedures of parties who will use and further develop such traditional knowledge for the welfare of mankind.

The inhibiting factors have not been registered applied art in it including the Gerabah craft from the Mare Island community. Gerabah (Boso Mare) has its own uniqueness but from the uniqueness there are some factors that have not been registered as, Mare Island people do not know the registration procedure at the Regional Office of the Ministry of Law and Human Rights of North Maluku, people assume that the Gerabah (Boso Mare) is an industry small one that do not need to be registered. The community thinks that the manufacture of Gerabah (Boso Mare) is difficult to imitate the community believes that only Mare Island people can make Gerabah (Boso Mare) besides the main ingredients for making Gerabah (Boso Mare) can only be found in Mare Island only.

\section{B. Pemahaman masyarakat PulauMareterhadap kerajinan pembuatan gerabah (BosoMare)sebagai hak} cipta traditional knowledge

Traditional knowledge is the result of human creations and thoughts either in the field of science, art or literature. This is in accordance with the purpose of the word creation that existed in Article 1 number 3 of Law Number 28 Year 2014 About Copyright, so thus basically the traditional knowledge can also be referred to as IPR. If in the system of Trade-Related Aspects of Intellectual Property Rights (TRIPs) determined the field of industry, science, literature and art. It can also be analogically found in traditional knowledge.

Traditional knowledge as well as applied arts including Gerabah or usually Mare Island community call it as (Boso Mare) is a handicraft that has existed from generation to generation people believe that the manufacture of this craft is only devoted to women alone that makes the men are strictly forbidden to make it, the men only help to take the materials, tools and sell it just because the people of Mare Island think if the men who make the craft Gerabah (Boso Mare) will get a disaster. Men only make handicrafts such as jars, glasses, and other ornaments of basic materials made of clay (Usman Alting, interview October 25, 2017).

The process of making Gerabah (Boso Mare) in Mare Island is:

a) The first process is the taking of land (Hale Malu), Mare Island community took the main ingredients to make pottery ie the land on the hill Mare Island.

b) The second process is the land that has been taken, in this process the people of Mare Island choose good quality soil for use in making Gerabah (Boso Mare). Then the ground that has been selected in the puree by the tool to get a good texture.

c) The third process is the drying of the soil, the soil that has been selected and in the puree then in the drying so that the soil is easily formed in the manufacture of Gerabah (Boso Mare).

d) The last process is burning Gerabah (Boso Mare), this process is an important process in making pottery because pottery with good quality can be seen from the burning.

Gerabah (Boso Mare) is used as a household appliance as well as a major livelihood for Mare Island community, especially Maregam Village. The making there is a division of labor by sex. Men do relatively heavier jobs, such as taking red soil, finding wood for burning, picking up sand, and selling it. Other materials such as red soil and sand taken from Halmahera, stone obtained from Pulau ternate. Women play a role soaking the material, mixing with sand, making pottery, drying and burning. Making Gerabah craft monthly income craftsmen community Rp. 5,000,000 to Rp. 7,000,000 million with the number of Gerabah 100 to 300 pieces.

The means of transportation used by the community of Mare Island at that time from the Year 1989 -2016 that is known as the Boat of the Engine (Ts, Katinting, $3 \mathrm{Gt}$ ) This boat is a boat that has been using a motorized Boat is a boat that is slightly smaller than the previous size of the Engine Boat between 10 X 5 meters of power boat is transporting 500-1000 Gerabah craft (Boso Mare), the time to sell it is estimated usually 20-30 Day. Until now the Mare community still survive with motorized boat transportation although the world is getting more sophisticated but the people of Mare Island more have use of traditional transportation to sell Gerabah (Boso Mare) to various regions in North Maluku. In addition, Gerabah craft is the main target of Village Owned Enterprises (BUMDes) Ahu ma joma especially Maregam Village to raise the level of welfare of the village community through the original income of the village. Gerabah handicraft (Boso Mare) is also a tourist industry that can attract the interest of local and foreign tourists, media, and scientists throughout the archipelago even extends to other countries. So that the Village Government of Maregam cooperates with BUMDes through the Village Fund Trying to optimize the development of Gerabah handicraft (Boso Mare) as the Superior Program and prioritized in 2018 allocated through the Village Fund 2018. 
Craftsmen at Pulau Mare Island do not understand the traditional knowledge possessed in this case Gerabah (Boso Mare). They assume that pottery is only a small industry that does not need to be registered to obtain legal protection for ownership of the work of the traditional copyright. In addition there is no socialization from the local government about the importance of legal protection, so that the community and the Government of Pulau Mare Village do not register the Gerabah craft (Boso Mare) (Hadija Aling, interview, October 25, 2017).

Departing from the above explanation, according to the author, although the Gerabah craft or (Boso Mare) in Mare Island is the result of a small industry but needs to be registered in the event of Gerabah (Boso Mare) is a traditional art that must be maintained and developed by the community and local government, because only in Central Island manufacture of earthenware vessels (Boso Mare) in North Maluku. The people of Mare Island and Local Government are not aware that the knowledge of traditional art of Gerabah (Boso Mare) has economic value. People also do not understand the concept of IPR, let alone to use it.

In addition, people's ignorance about the importance of legal protection of Traditional art of making Gerabah (Boso Mare). coupled with the existence of Village Enterprises to promote Mare Island tourism and introduce handicrafts to the wider community of Gerabah (Boso Mare) is expected for Local Government and Village Government also pay special attention in the case of registered to obtain legal protection. Frightened in the future there are imitations or claim the craft as their own property. Gerabah (Boso Mare) is a regional asset that must be protected so that Gerabah (Boso Mare) can compete with pottery from other regions in Indonesia.

\section{Conclusion and Recommendation}

Making of Gerabah (Boso Mare) with excellent quality and again the making of a copyrighted work in say as traditional knowledge should be registered to obtain proof of ownership of the traditional artwork owned area. The people of Mare Island have not understood the question of traditional knowledge and Law No. 28 Year 2014 on Copyright. In addition, the community's lack of knowledge about the importance of legal protection of Traditional art of making Gerabah (Boso Mare).

The importance of legal protection of traditional knowledge in this case Gerabah (Boso Mare) is expected to the community and village government to pay more attention to the special craft of Mare Island by registering Gerabah (Boso Mare) to obtain proof of ownership of a copyrighted work by the Law Number 28 Year 2014 on Copyright.

The lack of understanding of Mare Island community of Gerabah (Boso Mare) copyrights of traditional knowledge is expected by local government to do more socialization to Mare Island community about traditional knowledge and efforts of village and local government in protecting traditional culture especially traditional craft which is a regional asset that must be protected so that Gerabah craft (Boso Mare) can compete with pottery craft from other areas in Indonesia.

\section{References}

Abdul R. Saliman, 2006, Hukum Bisnis Untuk Perusaha, Prenada Media Group, Jakarta.

Afrillyanna Purba, 2009, Perlindungan Hukum Seni Batik Tradisional, $1^{\text {st }}$ Edition, Alumni, Bandung.

Arif Lutviansori, 2010, Hak Cipta dan Perlindungan Folklor di Indonesia, Graha Ilmu, Yogyakarta.

Amiruddin and Zainal Asikin, 2012, Pengantar Metode Penelitian Hukum, Raja Grafindo, Jakarta.

Bahder Johan Nasution, 2008, Metode Penelitian Ilmu Hukum, Mandar Maju, Bandung.

Budi Agus Riswandi and M. Syamsudin, 2005, Hak Kekayaan Intelektual dan Budaya Hukum, Raja Grafindo Persada, Jakarta.

Eddy Damian, 2002, Hukum Hak Cipta, Alumni, Bandung.

Endang Purwaningsih, 2006, Perkembangan Hukum Intellectual Property Rights, Ghalia Indonesia, Jakarta.

Gatot Supramono, 2010, Hak Cipta dan Aspek-Aspek Hukumnya, Rineka Cipta, Jakarta.

OK. Saidin, 2010, Aspek Hukum Hak Kekayaan Intelektual (Intellectul Property Rights), Raja Grafindo Persada, Jakarta.

Otto Hasibuan, 2008, Hak Cipta di Indonesia Tinjauan Khusus Hak Cipta Lagu Neighbouring Rights dan Collecting Societ, Alumni, Bandung.

Peter Mahmud Marzuki, 2010, Penelitian Hukum, Pernada Media Group, Jakarta.

Tim Lindsey, 2011, et.al., Hak Kekayaan Intelektual, Alumni, Bandung.

Widarto, 1995, Membuat Gerabah, Kanisius, Yogyakarta. 
Yusran Isnaini, 2010, Buku Pintar HKI, Ghalia Indonesia, Bogor.

\section{Regulation}

Law of the Republic of Indonesia No. 28 Year 2014 on Copyrights.

Law of the Republic of Indonesia No. 7 Year 1994 on Ratification Agreement Establishing the Word Trade Organization.

\section{Journal}

Sefritarinie, Landasan Konseptual Perencanaan dan Perancangan Pusat Seni Rupa di Yogyakarta Dengan Analogi Bentuk, https://www.ejournal.uajy.ac.id. htm. Last accessed on July 1, 2017.

Emma Valentina Tereska Senewe, Efektivitas Pengaturan Hukum Hak Cipta Dalam Melindungi Karya Seni Tradisional daerah. https://www.ejournal.unsrat.ac.id/htm. Last accessed on July 1, 2017.

Laina Rafian and Qoliqina Zolla Sabrina, Perlindungan bagi 'Kustodian' Ekspresi Budaya Tradisional Nadran Menurut Hukum Internasional dan Implementasinya Dalam Hukum Hak Kekayaan Intelektual di Indonesia, https://www.jurnal.unpad.ac.id.htm. Last accessed on July 14, 2017. 